\title{
Creating a Pocket-Friendly Theatre in Nigeria through the Socialmedia: An Experiment with Ahmed Yerima's The Sisters Video Upload
}

\author{
Sunday Edum (Corresponding author) \\ Department of Theatre and Film Studies, University of Port Harcourt
}

Nigeria

E-mail: sunday.edum@uniport.edu.ng

$\begin{array}{lr}\text { Received: August 19, } 2019 & \text { Accepted: April 2, } 2020 \quad \text { Published: June 20, } 2020 \\ \text { doi:10.5296/ijch.v7i1.17221 } & \text { URL: https://doi.org /10.5296/ijch.v7i1.17221 }\end{array}$

\begin{abstract}
Theatre practice in Nigeria is facing a general decline due to factors that are very glaring. One of such factor is the digital culture that has forced citizens to live a private live that is more comfortable and thereby reducing patronage. In spite of this obvious fact our Nigerian theatre is still ignoring the effective application of these digital network sites especially the social media in redeeming the declined image of the theatre industry. This study uses the literary and artistic methodologies to examine the video upload of Ahmed Yerima's The Sisters with a view of creating a template for creating a pocket-friendly theatre through the social media. The study therefore, observes that most of the video uploads posted on social media sites are merely for social reasons without commercial drive. It also observes that theatre practitioners in Nigeria are not profit driven but social driven in the practice of their art. The paper therefore, recommends strongly a culture of video upload for commercial reasons, commercialization of websites in most Nigerian universities to generate money for the university and the theatre and improvement on the technical quality of the video uploads.
\end{abstract}

Keywords: Pocket-Friendly, Social media, Video upload and live theatre

\section{Introduction}

Theatre, as an art form, has remained one of the greatest artistic instruments of man in an attempt to satisfy his personal desires, social environment and his perceived creator. In an attempt to entertain, educate and enlighten, theatre communicates man's needs, ideologies, expectations and worldview through the medium of stage, radio, film, cinema and recently the internet. Theatre is man's creation that manifests in song, dance, acting, pantomime, art 
works, architecture and festivals. Wright (1972) corroborates our position above when he states that:

Man created theatre in his own image. He was fully aware that the world was filled with hate, discord, unhappiness, rivalries misfortune, misunderstanding, conflict, war and destruction but he also knew that there was an abundance of kindness, generosity, love of mankind, brotherhood, fun, excitement, joy, contentment, and personal satisfaction. Symbolically, he chooses two masks to represent his creation: a mask of tragedy, that wept and a mask of comedy that laughed. (p.3)

Indeed man's attempt to fully understand his environment and discover his hidden possibilities has led to his creation of theatre. This informs why the concept of theatre does not respect personality, class, age, dimension, race and educational qualifications in addressing issues. It explains why there is comedy, tragedy, farce, melodrama, conventional and unconventional styles and genres. Theatre mirrors life through its elements and consciously seeks for solution to the challenges of life through entertainment, enlightenment and escape. Wrights (1972, p.3) states further that:

...its very ingredient has kept it alive, for here man has always spoken to man. They have discussed their joys, their sorrows, their problems, their idiosyncrasies, and their very existence and always in the presence of their fellow men- the audience.

In spite of the functional dimensions of theatre globally, the practiced of this very viable profession has been surrounded by myriad of challenges. The search for a solution to the declining state of theatre practice in Nigeria is not new in the scholarly landscape of Nigeria. For example, Dapo Adelugba, Wole Soyinka, Femi Osofisan, Olu Obafemi, Austin Sagba, Kalu Uka, Sam Ukala, Alex Asigbo and Emmanuel Dandaura, Tracy Utoh-Ejeazugh and Canice Nwosu etc. have written different papers in this regards. Ayakoroma in his work entitled "Reinventing Theatre practice in Nigeria: Leveraging on the Power of the Television Medium" has reviewed the opinions of such scholars as Saint Gbilekaa, Sam Ukala, Ofoneme Inyang, Femi Osofisan and Austin Asagba. In this thesis, Ayakoroma( 2017, p.2) quotes Saint Gbilekaa who observes that while the 1970s saw the establishment of Theatre Arts Departments in Nigerian Universities, as well as several States Arts Councils, making theatre practice in Nigeria to reach its peak where artistic colour from talented actors endeared them to their audiences, the situation soon witnessed a downturn. He opines, however, that the only hope to rescue the declining state of theatrical practice in Nigeria, barring funding constraints, lies within our university system where live theatre still attracts audience

Similarly, Femi Osofisan in his examination of the political and economic emancipation dimensions of theatre in Africa, calling for a serious commitment on the part of the practioners to revive the noble profession. He argues that:

live theatre can be used to preach "the virtues of socialism," since the old doctrine of "arts for art's sake" has gradually been relegated to the 
background, and that there is no denying the fact that the theatre can indeed go beyond just being for entertainment or mere formalistic experiments (cited in Ayakoroma p.3).

Identifying the dynamics of the television medium, Ayakororma is of the opinion that theatre can be resuscitated through the television medium. According to him: "'once theatre events are given prominence on television, through strategic promotions, the target audience will respond positively and eventually take the necessary action: patronage of the theatre" $(6)$. He Proposes an eight points agenda as strategies of redeeming and promoting theatre practice through the television medium thus:

\section{... News Reports, Promos/Adverts, "On Stage LIVE," "Follow-Spot," "Theatre Panorama," "Children's Theatre on TV," "TV Play Reading Sessions," and "Talking Theatre," among others; what, for now, could be termed, an 8-Point Agenda.(Ayakoroma, p. 6)}

Although Ayakoroma's eight point agenda appears very enticing and solution driven, but one must point out that the promotion of theatre is not the problem affecting theatre practice. This is because even thus who are aware of a performance taking place will still not attend if he have something more serious to attend. The problem is rather lack of interest from both members of the audience and the practitioners as a result of the crude method of production and presentation as well as lack of appreciable profit.

The postindustrial age has been dominated with digital technology were communication is easier and freer. These technological innovations have affected different communication and manufacturing sectors across Africa and the environment which man dwells. According to Johnson (2003)

Technology is rapidly changing the environment in which we live. All fields of study adapt to technology, constructing new and innovative ways to use technology to improve business operations. Recent developments and enhancements in digital technologies have altered the ways that many individuals and businesses function. With current technologies, the collection and distribution of information can be accomplished at lightning speeds, in almost any location, and within a global network. (p.2)

In the midst of these current developments, the theatre cannot be an exception in embracing these technological innovations in order to compete with her other communication performance counterparts like film. The globalized nature of the society and the euphoria of the Nigerian audience to meet up with the postindustrial age even in the midst of poor technology make technological improvement in the theatre inevitable. Indeed, Moltenbrey's position that the "current generation is hardwired to process multiple streams of dynamic visual information almost instantaneously" (cited in Johnson p.2) is highly instructive for the Nigerian theatre experts.

It is therefore important that theatre practitioners embrace the reality of the time to revive the 
interest and promote theatre practice in Nigeria in this digital age by utilizing the social media/networks. As Court rightly notes:

...the 21 st century workforce has realized that a command and knowledge of digital technologies has become a required skill for success. As technology changes the ways that we function in society, it is imperative that we adapt and integrate new technologies to best serve our respective fields (p.7).

Upon the above premise therefore, this work will examines the challenges and prospects of theatre practice in Nigeria in a post industrial age

\section{Survey Statement of Digital Theatre}

The concept of digital theatre is simple the realization or expression of a performance idea through the use of digital technology. There are digital theatre performances that have come to be theories as a result of constant applications by scholars and theorists. The term Cybertheater is credited to the Russian kinetic arts group Dvizjenije (which means Motion or Movement). Dvizjenije was an interdisciplinary team that, inspired by the 'cosmic' ideas of the Malevich tradition, was concerned with constructivism and kinetic art. They created work across the fields of visual arts, music, design, and education. Their piece Cybertheater (1967) was an immersive mechanic environment that invited audiences to enter into a world both virtual and physical, thus partaking in a communal sensual experience (Chatzichristodoulou 2). Some of the digital theatre genre examples Maria Chatzichristodoulou has identified include, Cyberformance, Digital theatre, Networked Performance Cybertheaters, VirtualTheatres, Digital practice, Telematic theatre and Cyber-theater. These twenty-first century performance styles are conditioned by digital technology. Tracing the emergence of these different theatre experimentations using cybertheater as an analytical model, Chatzichristodoulou informs that Cybertheater was a vision of man-machine symbiosis. Its title and Nusberg's discussion point to the discovery of cybernetics, defined by Norbert Wiener in 1948 as the science of "control and communication in the animal and the machine".(p.4) Underlying cybernetics was the idea that all control and communication systems, "be they animal or machine, biological or technological, can be described and understood using the same language and concepts".( Nusberg p.5)

In similar historical account, Stephen, traces the emergence of digital theatres to the early 1980s when video, satellites, fax machines, and other communications equipment began to be used as methods of creating art and performance. He identified Fluxus and John Cage groups as some of the early leaders in expanding what was considered art, technology, and performance. With the adaptation of personal computers in the 1980s, new possibilities for creating performance communications was born. Artists like Sherrie Rabinowitz and Kit Galloway began to transition from earlier, more costly experiments with satellite transmission to experiments with the developing internet. Online communities such as The Well and interactive writing offered new models for artistic creativity.(Wikipedia p.2).

Another foundational pointer to the development of the digital theatre is the 'Dot Com' boom 
of the 1990s that prompted telematic artists including Roy Ascott began to develop greater significance as theatre groups like George Coates Performance Works and Gertrude Stein Repertory Theatre established partnerships with software and hardware companies encouraged by the technology boom. Furthermore, in the early 1990s in Australia Julie Martin's Virtual Reality Theatre presented works at the Sydney Opera House, featuring the first hybrid human digital avatars, in 1996 "A Midsummer Night Dream featured Augmented Reality Stage sets designed and produced by her company. Researchers such as Claudio Pinanhez at MIT, David Saltz of The Interactive Performance Laboratory at the University of Georgia, and Mark Reaney head of the Virtual Reality Theatre Lab at the University of Kansas, as well as significant dance technology partnerships (includling Riverbed and Riverbed's work with Merce Cunningham) led to an unprecedented expansion in the use of digital technology in creating media-rich performances (including the use of motion capture, 3D stereoscopic animation, and virtual reality as in The Virtual Theatricality Lab's production of The Skriker at Henry Ford Community College under the direction of Dr. George Popovich. Another example is the sense:less project by Stenslie/Mork/Watz/Pendry using virtual actors that users would engage with inside a VR environment. The project was shown at ELECTRA, Henie Onstad Art Center, Norway, DEAFA 1996 in Rotterdam and the Fifth Istanbul Biennial (1997).

Early use of mechanical and projection devices for theatrical entertainments have a long history tracing back to mechanicals of ancient Greece and medieval magic lanterns. But the most significant precursors of digital theatre can be seen in the works of the early 20th century. It is in the ideas of artists including Edward Gordon Craig, Erwin Piscator (and to a limited degree Bertolt Brecht in their joint work on Epic Theatre), Josef Svoboda, and the Bauhaus and Futurists movements that we can see the strongest connections between today's use of digital media and live actors, and earlier, experimental theatrical use of non-human actors, broadcast technology, and filmic projections.(Wikipedia p.3)

The presence of these theatrical progenitors using analog media, such as filmic projection, provides a bridge between Theatre and many of today's vast array of computer-art-performance-communication experiments. These past examples of theatre artists integrating their modern technology with theatre strengthens the argument that theatrical entertainment does not have to be either purist involving only "live" actors on stage, or be consumed by the dominant televisual mass media, but can gain from the strengths of both types of communication.(Wikipedia 6)

\section{Challenges of Theatre Practice in a Digital Age}

\subsection{Lack of Appreciation of Performances}

One of the greatest threats to live theatre is the emerging trends in communication and entertainment channels. The digital age or a postindustrial age as some scholars like Frank Ugiomoh will call it has pushed theatre to the dunghill and make people not to appreciate it anymore. Nigerians like every third world nation appreciates what is in vague without necessarily questioning the implications of it. They will rather associate themselves with the cinema, movie premier, comedy shows than visiting a theatre house for a stage play. 


\section{MInstitute Mach $^{m+1}$}

International Journal of Culture and History

ISSN 2332-5518

2020, Vol. 7, No. 1

The emergence of the social media makes the theatre to be old fashioned especially for the youths. Those who even go to productions do so not because they appreciate it but because sometimes they are forced to by certain factors. These factors will include, free tickets, cheap tickets, lover's involvement in the production, proximity and for students most times for assignment purposes. It has been observed in a survey conducted in the University of Port Harcourt and Niger Delta University that even students and lecturers who are in the Department of Theatre Arts do not appreciate what they are been trained for or practicing. Most students shy away from productions either as actors or audience while some lecturers may not even attend productions except they are forcefully made examiners. This attitude is a display of lack of interest and appreciation of the Theatre productions. For those who manage to visit the theatre, while the production is on they spend more time with their phones on social media sites than the production they have been invited with free tickets. This attitude is not unconnected with the age and Nigerian mentality of elitism because the approach of theatre practice does not attract appreciation from members of the audience.

\subsection{Discrimination of Practitioners}

There is a strong discrimination of Nigerian theatre artists in the post industrial age. People prefer to attend to music stars and film stars but no one reorganizes the stage permanence star in public gatherings. This informs why there is a serious cross-over of our stage theatre graduates to the film industry dues to this discriminatory stigma. I can remember a study we carried out among undergraduate students of the Department of Theatre Arts on their future dream upon graduation. In this study, we observed that 97 percent of the respondents have no dream of venturing into stage performances but are interested in film acting, directing, costume and makeup, lighting, sound etc. the reason they gave was that theatre is no longer viable and does not give food anymore and that the possibility of becoming a star as a stage actor is impossible. Most of them even though they are in the Department of theatre arts, their target is in the film industry and other digital stations not arts councils and other theatre play houses. Those who still hold on to theatre practice are few in number due to the perception and poor image building mechanism that theatre has in the digital age.

\subsection{Lack of Profit}

The digital age suppresses theatre to poverty due to the marketable limitations of the crude approach of conventional theatre practice. One of the greatest challenges of theatre practice in a capitalist economy is lack of profit. 90 percent of theatre practitioners cannot comfortably eke out a living with returns from the production. Productions are marred with poor gate returns and sponsors are also not even interested in putting their monies in stage productions. Those who manage to do so, do it for charity purposes. This state is not encouraging for the practitioners and businessmen. It is important to mention that, arts for art sake may have resurfaced in Nigeria through government consistent efforts. Government's attempt at promoting the arts does not bring financial gain to her coffers at the end of the day. The different carnivals organized at the federal level in the name of NAFEST, ABUJA CARNIVAL etc. and different states like Calabar, Rivers and Imo States are not financially profiting. This explains the sustenance level of these events. In this digital era, the major interest of business enthusiast is profit not social and other gains. This implies that for a business to be competitive, it must have financial gains that attract business moguls to invest into it. The theatre 


\section{Macrothink}

has not been able to evolve a profit making mechanism online with the postindustrial age.

\subsection{Poor Patronage}

Among the studies carried out by different scholars on theatre practice, the major issue that preoccupy the thrust of their papers is the issue of poor patronage. This poor patronage is due to insecurity, poverty, unemployment, lack of competence and internal misunderstanding by the practitioners. The digital age gives room for individualism and since the conventional theatre demands her audience to gather in a specially designed building for entertainment, poor patronage is now the order of the day. People are busy satisfying themselves with online entertainment through different social media sites such as Facebook, Whatsaap, twitter, YouTube, Instagram, 2Go, LinkedIn etc. these digital experience makes people to be preoccupy in their different closet and the theatre suffers. The film and musical videos have also taken the audience as they can easily buy a $\mathrm{CD}$ and take it home and watched at their own comfort.

\section{Creating a Pocket-Friendly: The Sisters Experiment}

\subsection{About the Play}

The Sisters is a social commentary on the tragedy of family secrets. The demise of Dikpo, the president and husband of Funmi ignites a serious revelations of different hidden secrets. In the spirit of mourning, influential Funmi shoves her kid sisters to join her in the mourning of her late husband. However, this invitation is more to the burial rite of her lovely husband as it later revealed that Dikpo had five children out of wedlock and have been brought as legal beneficiaries of Dikpo's inheritance. This shock of this revelation complicates the conflict as Taitai, Funmi's younger sister, rather than proffer solution to Funmi's traumatic situation, expresses her displeasure for the leadership style and high class attitude displayed by Funmi while she served as first lady. She recalls how her husband Joe was executed by Dikpo, Funmi's late husband after a failed coup and how she was brutally hit by a stray bullet that placed her on a wheel chair. The story takes a different turn as Funmi's fathers will reveals the unbelievable secret. Nana who has been like a Personal Assistant to Funmi and a surrogate mother of the three sisters is their biological elder sister; given birth to by their father out of wedlock. It is on this discovery note that the play ends.

\subsection{Directorial Concept}

One of the greatest renaissance dramatists Jean Racine, in his famous quotes posits that "there are no secrets that time does not reveal" it is on this premise that this performance finds it lesson to her esteemed audience.

\subsection{Preproduction}

From the day we decided to interpret this play, the social media was our main medium of communication. We did not use any analogue means to communicate to interested hands on the production. Whatsaup, Facebook, Instagram and BBM channels were our means of communication. We also used the same means to promote and market the production throughout the preproduction stage. The feedback from the social network communication style was very successful as we observed that over 1000 persons liked the page. And to further access the success of the use of 
social media to advertise productions a lot of persons turned up for the performance and the box office was impressive. Importantly also friends from far and near called to register apologies and show concern on the production.

\subsection{Online Videos}

Apart from live streaming, productions we also downloaded the video of the production online and a lot of persons viewed it across the world. Although the experiment was not for commercial purpose but response received is a strong signal that video uploads can generate money for the practitioners. Productions can be sold through as online videos to the public through the social media. This production should be professionally recorded with digital cameras and posted on social media sites for member of the audience to download and watch. As members of the audience download these online video, money is gemerated by the data used in subscription. The more people subscribe to the online production videos the more money the theatre generates.

Another example that readily comes to mind is the Crab TV, a website hosted in the Department of Theatre and Film, University of Port Harcourt in 2015, where production videos are uploaded for viewers. A statistical study revealed that of the different productions videos uploaded, one observes an encouraging interest by members of the public. For example Women of Owu received 1,864 (22\%) of viewers with 565 18\% downloads, Tears of a School Girl received 867 (12\%) and 562 viewers, The Gods Are Not to Blame received 614 (18\%) and 417 viewers. Although these productions are uploaded not for commercial purposes but the response if professionally recorded with a box office interest the amount of money that these production stands to generate will definitely generate a pocket-friendly theatre. For instance if we market these video at $1 \$$ per viewing of a video, Women of Owu will have generated \$ 1864 which is equivalent of N932000 within less than one hour. This experience is very encouraging for the theatre industry especially in a capitalist world where profit maximization is the thrust of most business.

\section{Conclusion}

Social media platforms can be used to enhance and complement the existing communications platforms utilized by different organizations. This is because most of these social media platforms create two-way communication. It can support to provide an update on the reputation of a theatre company through its production response. Through the awareness it creates to millions of social media users across the world, productions can be accesses from any part of the world through the pay as you go mechanism. This will increase the revenue generation of the theatre organization The greatest attraction that the theatre can get in this era of capitalism is profit maximization. This is because business enthusiast are interested in investing where they can maximize profit and the theatre does not provide this platform as we practice today. This paper therefore, advocates for a pocket friendly theatre that uses the social network for marketing and generating funds for all involved.

Apart from the video upload that the study has examined, the theatre can generate funds through live streaming of her productions to be able to reach a wider audience. One can recall 


\section{Ml Macrothink}

International Journal of Culture and History

ISSN 2332-5518

2020, Vol. 7, No. 1

that churches now use online streaming to get to her members to different parts of the world without necessary going to that area. For example Christ Embassy, Living Faith Church, Salvation Ministries etc. uses live streaming to breach to her members from their headquarters. Pastors now run satellite ministries and are succeeding gracefully in reaching their members in soul and mite. Similarly, the Premiership Football Competition and the Champion League has become more popular to Nigerians through live streaming. We experience this football the way Europeans who are in the stadium even when we are far from the venue. This presentation can be borrowed by the theatre to make her performance it more relevant, generate profit and compete with modern technology driven performances.

Live streaming can get to different parts of the world after an aggressive publicity through the social media. The theatre can market her products through different social media sites and as such the revenue of the theatre will increase tremendously and all participants will be properly paid for their services.

Based on the above, the increasing nature of digital culture in Nigerian has become pertinent that practitioners embrace it to maximize profits, promote stardom and above all revive theatre interest. This paper calls for an aggressive integration of digital technology especially the social media through marketing and production processes of productions. The use of digital technology will attract attention of all our lost patrons who are very busy with their phones, iPad, laptops, and computers accessing online resources. In doing this, the declining image of the theatre will be eliminated and profit will be maximized.

\section{References}

Auslander, P. (2012). From Acting to Performance: Essays in Modernism and Postmodernism. New York: Taylor \& Francis e-Library.

Ayakoroma, B. F. (2017). Re-inventing Live Theatre Practice in Nigeria: Leveraging on the Power of the Television Medium. [Online] Available: www.nico.gov.ng

Bharucha, R. (2015). Theatre and the World Performance and the Politics of Culture. London and New York: Taylor \& Francis e-Library.

Biographic.com Editors. (2017). Constantine Stanislavsky Biography. A\&E Television Networks: The Biography.com. [Online] Available: http://www.biography.com/people/constantin-stanislavski9492018 (October 26, 2016)

Bolter, D. Y., \& Grusin, P. (2000). Remediation: Understanding New Media. Cambridge, MA: MIT Press.

Cash, J. (2014). The Drama Teacher. http://www.thedramateacher.com [Online] Available: (November 2016)

David, P., \& Sophie, L. H. (2011). Digital Transitions and the Impact of New Technology on the Arts. Canadian Public Arts Funders (CPAF) Network.

Giannachi, G. (2004). Virtual Theatres: an Introduction. London and New York: Routledge. https://doi.org/10.4324/9780203500033 


\section{Macrothink}

Graz, A. (1994). Spacemaking: Experiences of a Virtual Body. Dance Theatre Journal, 11(3), $12-13 \& 46-47$.

Kelly. A. J. (2011). Theatrical Productions and Digital Technology Production Technology in Innovations in and Implications of Digital Regional Theatre.

Nusberg, L. (1974). “Cybertheater” Malina, Frank. J. Ed. Kinetic Art: Theory and Practice. Selections from the Journal Leonardo. New York: Dover. 104-107.

Popper, F. (1975). Art - Action and Participation. London: Studio Vista, Cassell \& Collier Macmillan.

Sauter, W. (2000). The Theatrical Event: Dynamics of Performance and Perception. Iowa City: University of Iowa press.

Schrum, A. S. (1999). Theatre in Cyberspace: Issues of Teaching, Acting and Directing. New York: Peter Lang.

Simkin, J. (1997). (john@spartacus-educational.com) (C) September 1997 (updated August 2014).

Turkle, S. (1997). Life on the Screen: Identity in the Age of the Internet. New York: Simon and Schuster.

Wright, E. (1972). Understanding today's Theatre. New Jersey: Prentice Hall, Englecliff.

\section{Copyright Disclaimer}

Copyright reserved by the author(s).

This article is an open-access article distributed under the terms and conditions of the Creative Commons Attribution license (http://creativecommons.org/licenses/by/3.0/). 